\title{
Study of Photoinduced Interaction between Calf Thymus-DNA and Bovine Serum Albumin Protein with $\mathrm{H}_{2} \mathrm{Ti}_{3} \mathrm{O}_{7}$ Nanotubes
}

\author{
Rajesh Chakraborty $^{1^{*}}$, Sriparna Chatterjee ${ }^{2}$, Sandipan Sarkar ${ }^{3^{*}}$, Pabitra Chattopadhyay ${ }^{1}$ \\ ${ }^{1}$ Department of Chemistry, Burdwan University, Burdwan, India; ${ }^{2}$ Institute of Physics, Bhubaneswar, India; ${ }^{3}$ Durgapur Institute of \\ Advanced Technology and Management, Durgapur, India. \\ Email: "bigrajesh86@gmail.com, ${ }^{*}$ sandipanbu@yahoo.co.in
}

Received June $21^{\text {st }}, 2012$; revised July $24^{\text {th }}, 2012$; accepted August $14^{\text {th }}, 2012$

\begin{abstract}
Hydrogen titanate nanotubes were synthesized by hydrothermal process using $10 \mathrm{M} \mathrm{NaOH}$ and $\mathrm{TiO}_{2}$ anatase powder. The material synthesized was characterized by X-ray diffraction (XRD), scanning electron microscopy (SEM) and transmission electron microscopy (TEM) to ensure the structural and morphological characteristics. The interaction of calf thymus DNA (CT-DNA) and bovine serum albumin protein with suspended aqueous solution of titanate nanotubes was investigated using UV absorption spectroscopy and the apparent association constant was found to be, $\mathrm{K}_{\mathrm{b}}=1.68 \times$ $10^{4} \mathrm{M}^{-1}$ and $\mathrm{K}_{\mathrm{ap}}=5.41 \times 10^{3} \mathrm{M}^{-1}$ for DNA and BSA respectively. Addition of the titanate nano material resulted quenching of fluorescence spectra of ethidium bromide-DNA in tris $\mathrm{HCl}$ buffer solution and that of aqueous protein solution. The apparent binding constant $\left(\mathrm{K}_{\mathrm{sv}}=5.46 \times 10^{4} \mathrm{M}^{-1}\right.$ for DNA binding and $\mathrm{K}_{\mathrm{sv}}=6.063 \times 10^{3} \mathrm{M}^{-1}$ for protein binding) was deduced from relevant fluorescence quenching data using Stern-Volmer equation.
\end{abstract}

Keywords: Photoinduced Interaction; Nanotubes; Hydrothermal Process

\section{Introduction}

One-dimensional nanostructures have drawn a great attention due to their potential applications in a variety of novel devices in recent past [1-5]. The most fascinating example of such nanostructure is of course carbon nanotubes. Several efforts were made to synthesize nanorods and nanowires of more complex structure and conesquently a number of one-dimensional nanomaterials including metals, oxides and nitrides have also been reported. Hydrothermal or solvothermal synthesis is an very important approach to produce oxidic nanowires and nanotubes because synthesis of these types provide access to uniform and distinct morphologies in large scales with remarkable reliability, selectivity, and efficiency [6].

Among the one-dimensional oxidic nanomaterials reported, titanium oxide is of particular interest for its wide applications as catalyst supports, semiconductor photocatalysts and sensors [7-9]. $\mathrm{TiO}_{2}$ nanoparticles are acting as biosensors in chemical and biochemical fields and their applications are becoming more extensive. These probes have been applied to the ultrasensitive detection of proteins, DNA sequencing, clinical diagnostics, etc. $\mathrm{TiO}_{2}$ nanoparticles have also been used as carriers for

*Corresponding authors. photosensitizer like porphyrins in photodynamic therapy for cancer treatment. Titanate nanotubes of nearly $8 \mathrm{~nm}$ in diameter were first reported by Kasuga and co-workers, employing a hydrothermal treatment of rutile $\mathrm{TiO}_{2}$ powders in strong aqueous solution of $\mathrm{NaOH}$ at $110^{\circ} \mathrm{C}$ followed by $\mathrm{HCl}$ washing [10]. Several number of papers were published afterwards on the structure of hydrothermally synthesized $\mathrm{TiO}_{2}$ which also gave birth of a number controversies. Finally Chen et al. concluded that these nanotubes were of $\mathrm{H}_{2} \mathrm{Ti}_{3} \mathrm{O}_{7}$ structure based on diffraction and high-resolution transmission electron microscopy (HRTEM) results [11].

Over the past decade a significant number of papers have been published on the specific interaction between photoactive nanocrystalline metal oxide semiconductor particles and DNA or proteins or other biomolecules [12-18]. Interestingly research works of these types open up the possibility of the electronic transduction of DNA sequence and hybridization, as well as development of new electrochemical probes for DNA-binding proteins, both of which are major challenges in bioelectronics $[16$, 19,20]. Deoxyribonucleic acid (DNA) is unique genetic molecule in any living organism. Consequently the qualitative and quantitative analysis of nucleic acids is 
attracting a great attention because this is the material base of genetic inheritance. On the other hand Serum albumin is the most plentiful protein in blood plasma. It is a large globular protein containing 582 amino-acid residues with a molecular weight of 69,000 Dalton and two tryptophan moieties at positions 134 and 212 as well as tyrosine and phenylalanine [21] Each protein molecule can carry seven fatty acid molecules. They bind in deep crevices in the protein, burying their carbon-rich tails safely away from the surrounding water. Serum albumin also binds to many other water-insoluble molecules. The strong affinity of BSA to the water molecules has made the protein an automatic choice for the interaction studies in the present work. Moreover BSA is used as protein model because of its stability, its lack of effect in many biochemical reactions, and its low cost. BSA has numerous biochemical applications including Enzyme-Linked Immunosorbent Assay immunoblots, and immunohistochemistry [22]. It is also used as a nutrient in cell and microbial culture. BSA is used to stabilize some enzymes during digestion of DNA and to prevent adhesion of the enzyme to reaction tubes. This protein does not affect other enzymes that do not need it for stabilization. The binding properties of BSA with various drugs have been fully investigated by many researchers [23-25]. In this present work, interaction between suspended $\mathrm{H}_{2} \mathrm{Ti}_{3} \mathrm{O}_{7}$ nanotubes (in aqueous solution) and CT-DNA, followed by BSA protein and was examined by UV and fluorescence spectroscopy. As the natural fluorescence intensity of DNA is very weak, ethidium bromide (EB) was used to enhance the fluorescence intensity while BSA shows intrinsic fluorescence due to the presence of aromatic amino-acid residues.

\section{Materials and Methods}

\subsection{Materials}

CT-DNA and $\mathrm{TiO}_{2}$ (AR grade) was purchased from Merck (Mumbai, India) while ehidium bromide and bovine serum albumin protein was purchased from Sigma Aldrich. Approximately $10^{-4} \mathrm{M}$ stock solution of CTDNA was prepared by dissolving proper amount of DNA in $1 \mathrm{M}$ tris buffer.

\subsection{Preparation of $\backslash$ Hydrogen Titanate Nanotubes (HTO)}

A $1.0 \mathrm{~g}$ potion of anatase $\mathrm{TiO}_{2}$ powder was dissolved in $10 \mathrm{M} \mathrm{NaOH}$ solution and the resulting suspension was then transferred in an autoclavable reaction chamber. The reaction chamber was autoclaved in an oven at a temperature of $130^{\circ} \mathrm{C}$ for 22 hours. The product was filtered after cooling down to room temperature and thoroughly washed with $1 \mathrm{M} \mathrm{HCl}$ and water to remove any trace of $\mathrm{NaCl}$ produced during washing [26]. Subsequently the material was dried at ambient temperature.

\subsection{Characterization of HTO}

The powder X-ray diffraction (XRD) data were recorded from a PANalytical X'pert Pro diffractometer with $\mathrm{Cu}$ $\mathrm{K} \alpha$ radiation. The morphology of the nanostructured samples was studied with use of a Jeol JSM-840 scanning electron microscope (SEM) operating at $120 \mathrm{keV}$. TEM studies of nanotubes were carried out with a FEI Tecnai TEM equipped with $\mathrm{LaB}_{6}$ filament and operated at $200 \mathrm{kV}$. TEM samples were prepared by placing a drop of the ultrasonically dispersed powder (in ethanol) on a carbon-coated copper grid and drying in air.

\subsection{Fluorescence Quenching Measurements}

A Hitachi F-4500 fluorescence spectrophotometer was used to perform the fluorescence quenching measurements. The excitation wave length of EB-DNA was kept fixed at $522.0 \mathrm{~nm}$ while the emission wave length was chosen at $400.0 \mathrm{~nm}$. The excitation and emission slit length ( $5 \mathrm{~nm}$ and $10 \mathrm{~nm}$ respectively) wave lengths as well as the scan speed $(2400 \mathrm{~nm} / \mathrm{min})$ were kept fixed throughout the experiment. For BSA-HTO interaction study the excitation and emission wavelength was kept fixed at $510 \mathrm{~nm}$ and $435 \mathrm{~nm}$ respectively with all the other conditions remaining the same as before.

\subsection{Absorption Spectral Measurements}

To carry out the absorption spectral measurements, a JASCO V-570 UV-Vis spectrophotometer was used. For each measurement, $4.0 \mathrm{~mL}$ solution, containing DNA, suspended solution of nanoparticle and tris buffer was taken. At first the UV-vis spectrum was recorded for a solution without DNA. For the rest of the solutions, DNA was added with an increment of $0.05 \mathrm{~mL}$ each and then the spectra for all the solutions were recorded in the range of $200-800 \mathrm{~nm}$. BSA absorbs light energy around $280 \mathrm{~nm}$. So the absorption spectra for purely aqueous solution of BSA $\left(10^{-2} \mathrm{M}\right)$ was recorded at the beginning and then suspended aqueous solution of HTO was added.

\section{Results and Discussions}

\subsection{Structural and Morphological Studies of HTO}

X-ray diffraction pattern of HTO is shown in Figure 1 This diffraction pattern mostly matches with the monoclinic crystal structure of $\mathrm{H}_{2} \mathrm{Ti}_{3} \mathrm{O}_{7}$ (space group $\mathrm{C} 2 / \mathrm{m}$ (12)) (JCPDS Card no. 41-0192). Figure 2 shows the 


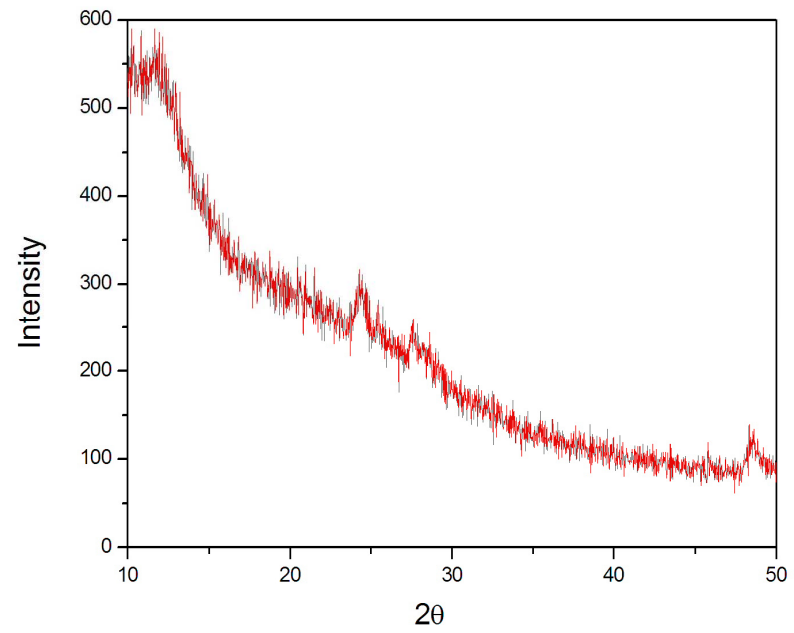

Figure 1. XRD spectra of HTO.

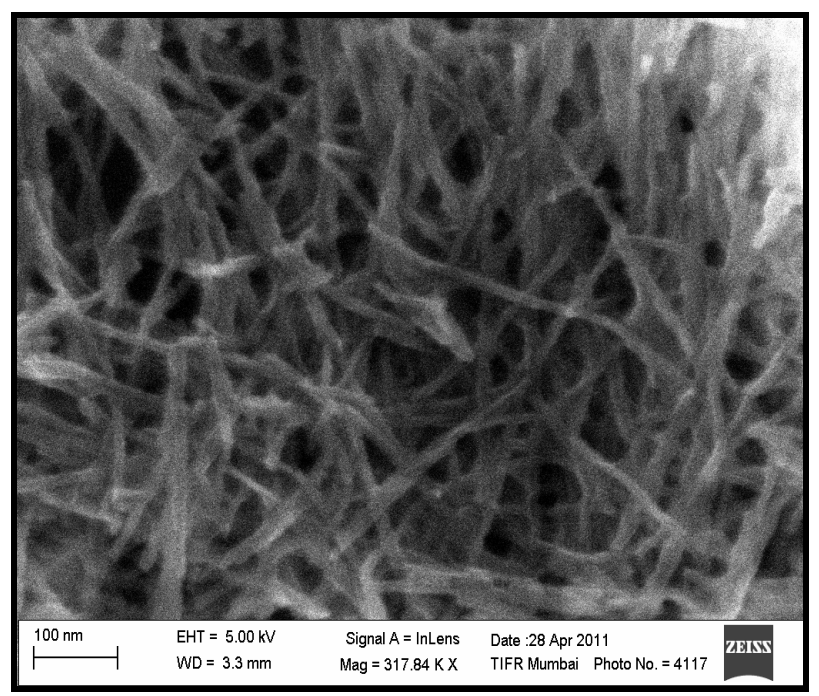

Figure 2. SEM image of $\mathrm{H}_{2} \mathrm{Ti}_{3} \mathrm{O}_{7}$ nanotubes.

SEM images of the nanostructured samples hydrothermally synthesized from anatase powder. The scanning electron micrograph shows the formation of one dimensional (1-D) nanostructures. Further TEM study (Figure 3) clearly shows that the each 1-D units are actually hollow, multiwalled nanotubes with inner diameter of $4-5$ $\mathrm{nm}$ and the outer diameter of $9-10 \mathrm{~nm}$.

\subsection{UV Absorption Study by CT DNA and BSA with HTO}

Figure 4 shows the absorption spectra of CT-DNA in presence of suspended aqueous solution of HTO. The concentration of suspended HTO was kept constant for all sets of experiments while the concentration of DNA was increased uniformly. In presence of HTO the absorbance of DNA increases considerably with increasing concentration of DNA. Similar type of experiment was

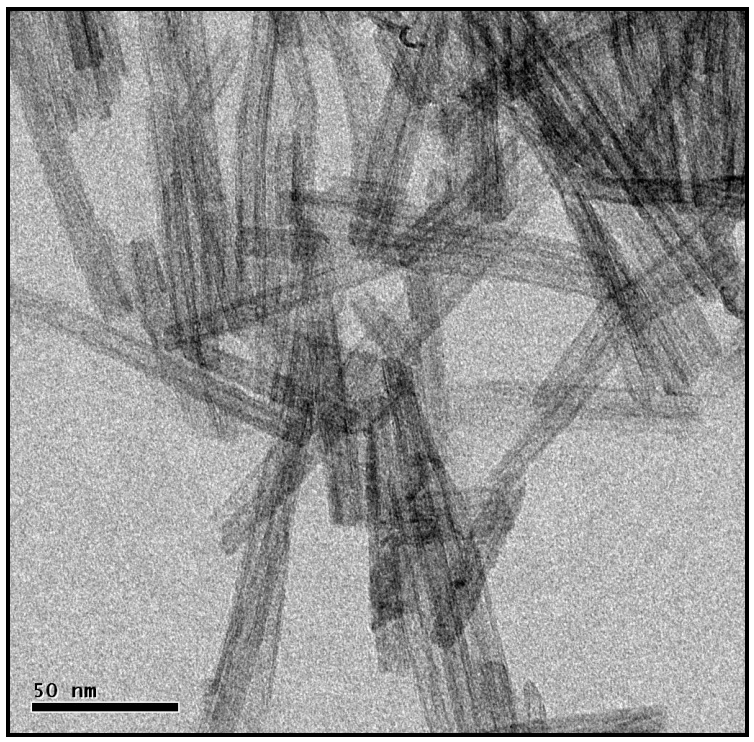

Figure 3. TEM image of $\mathrm{H}_{2} \mathrm{Ti}_{3} \mathrm{O}_{7}$ nanotubes.

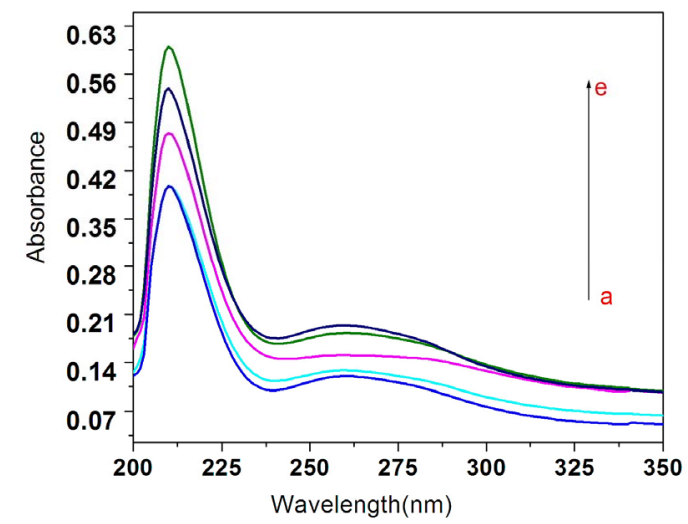

Figure 4. Electronic spectral titration HTO with CT-DNA at $266 \mathrm{~nm}$ in tris-HCl buffer; [HTO] $=2.5 \times 10^{-5}$; [DNA]: (a) 0.0 , (b) $6.2 \times 10^{-6}$, (c) $10.0 \times 10^{-6}$, (d) $15.2 \times 10^{-6}$, (e) $20.6 \times$ $10^{-6} \mathrm{~mol} \cdot \mathrm{L}^{-1}$. Arrow indicates the direction of change upon the increase of DNA concentration.

performed with BSA and HTO and the only difference is that the concentration of BSA was kept constant throughout the experiment. Figure 5 shows the gradual increase of absorption spectra with increasing concentration of HTO. To make it confirm that the absorption change which we observed in the spectrum was not due the experimental error, baseline corrections were done for all the measurements. Therefore the results clearly indicate that there is a interaction between suspended HTO and CT DNA/BSA through the formation of some complex of the type $\mathrm{HTO}_{7} \mathrm{DNA}$, HTO-BSA $[27,28]$.

\subsection{Fluorescence Quenching Study of EB-CT DNA by HTO}

As it has been mentioned earlier that the natural fluores- 
cence intensity of DNA is very weak, ethidium bromide (EB) was used as fluorescence probe for DNA. Figure 6 shows that addition of suspended aqueous solution of HTO to a solution of EB-DNA resulted in a decrease in fluorescence emission intensity of EB-DNA. HTO solution was added in increasing concentration keeping the EB-DNA concentration constant for all the measurements. Fluorescence quenching study of BSA was carried out in similar fashion keeping the concentration of BSA solution fixed. Figure 7 shows the quenching of

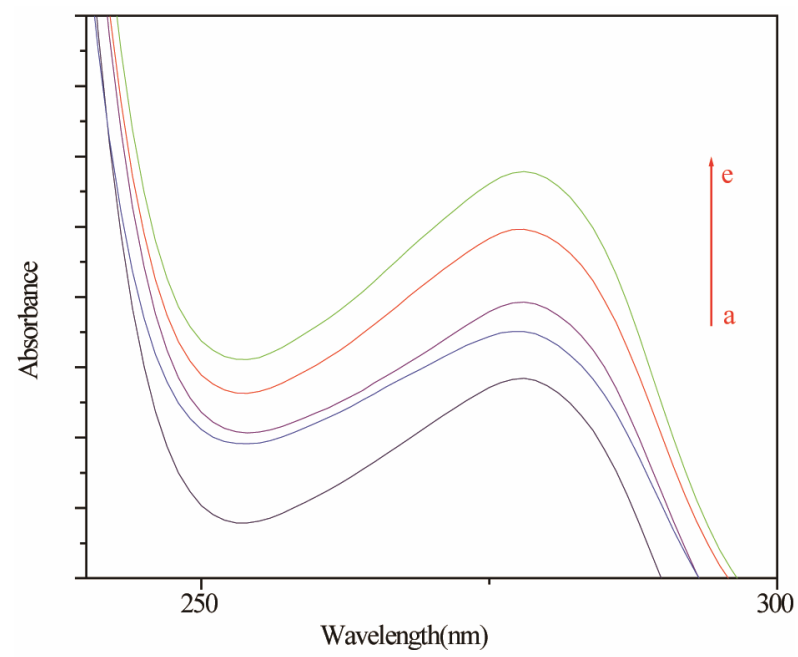

Figure 5. Electronic spectral titration of HTO with BSA at $280 \mathrm{~nm}$ in water.[BSA] is constant and [HTO]: (a) $1.25 \times$ $10^{-5}$; (b) $2.5 \times 10^{-5}$; (c) $3.75 \times 10^{-5}$; (d) $5.0 \times 10^{-5}$; (e) $6.25 \times$ $10^{-5} \mathrm{~mol} \cdot \mathrm{L}^{-1}$. Arrow indicates the direction of change upon the increase of HTO concentration.

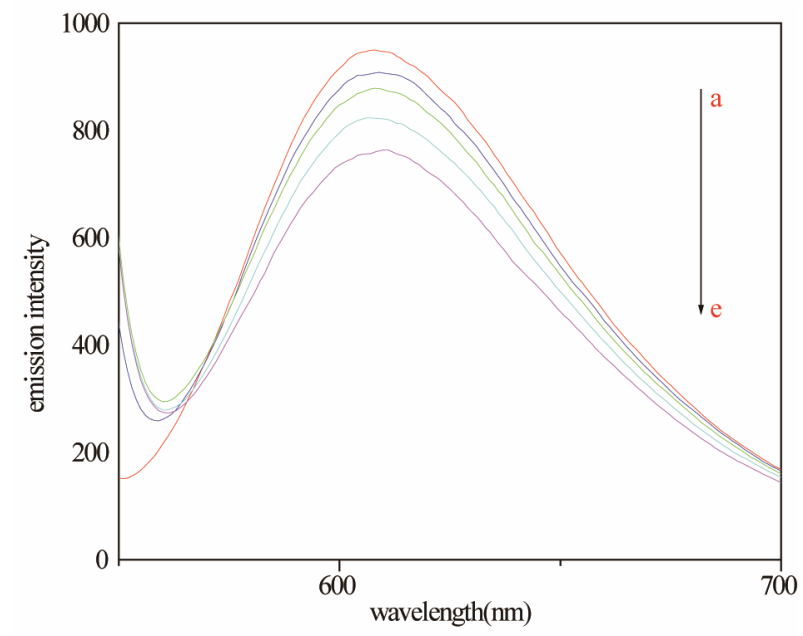

Figure 6. Emission spectra of the CT-DNA-EB system in tris-HCl buffer upon the titration of the HTO. $\mathrm{k}_{\mathrm{ex}}=522 \mathrm{~nm}$; $[\mathrm{EB}]=9.6 \times 10^{-5} \mathrm{~mol} \cdot \mathrm{L}^{-1}$; [DNA] $=1.25 \times 10^{-5}$; [Complex]: (a) 0.0 ; (b) $1.25 \times 10^{-5}$; (c) $2.5 \times 10^{-5}$; (d) $3.75 \times 10^{-5}$; (e) 5.0 $\times 10^{-5} \mathrm{~mol} \cdot \mathrm{L}^{-1}$. Arrow shows the intensity change upon the increase of the complex concentration.

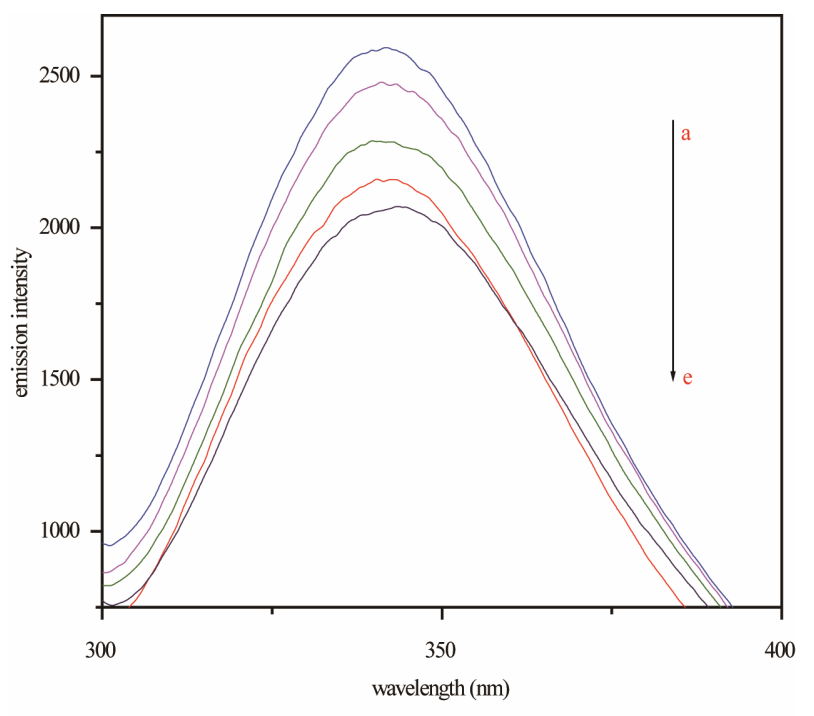

Figure 7. Emission spectra of the aqueous solution of BSA upon the titration of the HTO. [BSA] is constant [HTO]: (a) $1.25 \times 10^{-5}$; (b) $2.5 \times 10^{-5}$; (c) $3.75 \times 10^{-5}$; (d) $5.0 \times 10^{-5}$; (e) $6.25 \times 10^{-5} \mathrm{~mol} \cdot \mathrm{L}^{-1}$. Arrow indicates the direction of change upon the increase of HTO concentration.

BSA protein with increasing concentration of HTO. Baseline correction was done for all the measurements to get rid of the probable scattering effect due to the suspended nature of HTO in aqueous medium. It ensures that fluorescence quenching occurs only due to interacttion between CT DNA/BSA and HTO.

\subsection{Determination of Binding Constant between CT DNA and HTO}

In order to further illustrate the binding strength of the HTO with CT-DNA, the intrinsic binding constant $\mathrm{K}_{\mathrm{b}}$ was determined from the spectral titration data using the following equation:

$$
[\mathrm{DNA}] /\left(\varepsilon_{\mathrm{a}}-\varepsilon_{\mathrm{f}}\right)=[\mathrm{DNA}] /\left(\varepsilon_{\mathrm{b}}-\varepsilon_{\mathrm{f}}\right)+1 /\left[\mathrm{K}_{\mathrm{b}}\left(\varepsilon_{\mathrm{b}}-\varepsilon_{\mathrm{f}}\right)\right]
$$

where [DNA] is the concentration of DNA, $\varepsilon_{\mathrm{f}}, \varepsilon_{\mathrm{a}}$ and $\varepsilon_{\mathrm{b}}$ correspond to the extinction coefficient, respectively, for the free HTO, for each addition of DNA to the suspended solution of HTO and for the HTO-DNA complex in the fully bound form. A plot of $[\mathrm{DNA}] /\left(\varepsilon_{\mathrm{a}}-\varepsilon_{\mathrm{f}}\right)$ versus [DNA], gives $\mathrm{K}_{\mathrm{b}}$, the intrinsic binding constant as the ratio of slope to the intercept. From the $[\mathrm{DNA}] /\left(\varepsilon_{\mathrm{a}}-\varepsilon_{\mathrm{f}}\right)$ versus[DNA] plot (Figure 8), the binding constant $\mathrm{K}_{\mathrm{b}}$ for the HTO-DNA complex was determined to be $1.68 \times 10^{4}$ $\mathrm{M}^{-1}(\mathrm{R}=0.97208$ for four points).

Fluorescence intensity of EB bound to DNA at $522 \mathrm{~nm}$ shows a decreasing trend with the increasing concentration of the HTO (Figure 6). The quenching of EB bound to DNA by the titanate nanorods are in agreement with 
the linear Stern-Volmer equation:

$$
\mathrm{I}_{0} / \mathrm{I}=1+\mathrm{K}_{\mathrm{sy}}[\mathrm{Q}]
$$

where $\mathrm{I}_{0}$ and $\mathrm{I}$ represent the fluorescence intensities in absence and presence of quencher, respectively. $\mathrm{K}_{\mathrm{sv}}$ is a linear Stern-Volmer quenching constant, Q is the concentration of quencher. In the quenching plot (Figure 9) of $\mathrm{I}_{0} / \mathrm{I}$ versus [complex], $\mathrm{K}_{\mathrm{sv}}$ value is given by the ratio of the slope to intercept. The $\mathrm{K}_{\mathrm{sv}}$ value for the complex is $5.46 \times 10^{4}(\mathrm{R}=0.96771$ for four points), suggesting a strong affinity of the titanate nanorods to CT-DNA. Again the apparent binding constant $\left(\mathrm{K}_{\mathrm{ap}}\right)$ due to interaction between HTO with BSA can be determined following the equation:

$$
1 /\left[\mathrm{A}_{\mathrm{obs}}-\mathrm{A}_{0}\right]=1 /\left[\mathrm{A}_{\mathrm{c}}-\mathrm{A}_{0}\right]+1 / \mathrm{K}_{\mathrm{ap}}\left(\mathrm{A}_{\mathrm{c}}-\mathrm{A}_{0}\right)[\mathrm{HTO}]
$$

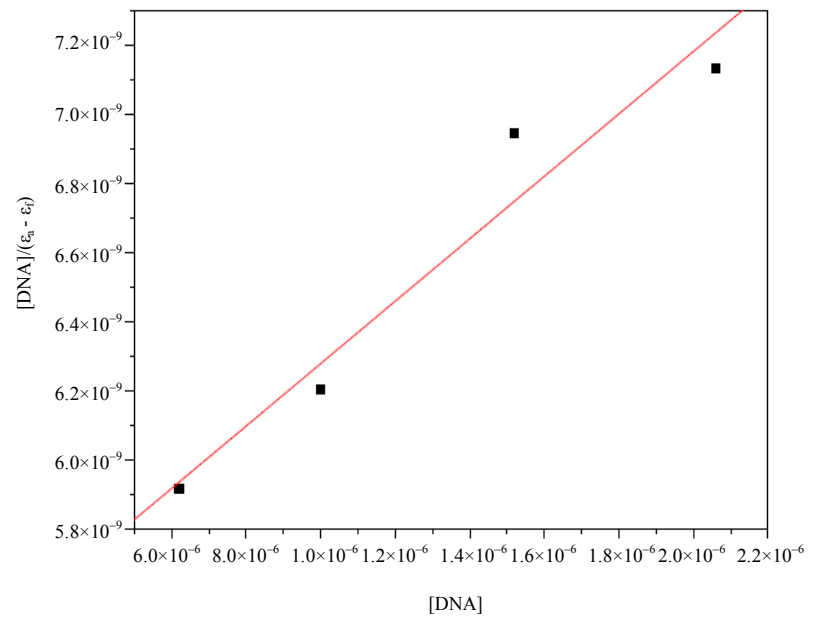

Figure 8. Plot of $[D N A] /\left(\varepsilon_{a}-\varepsilon_{f}\right)$ vs [DNA] for the absorption titration of CT-DNA with the HTO in Tris-HCl buffer.

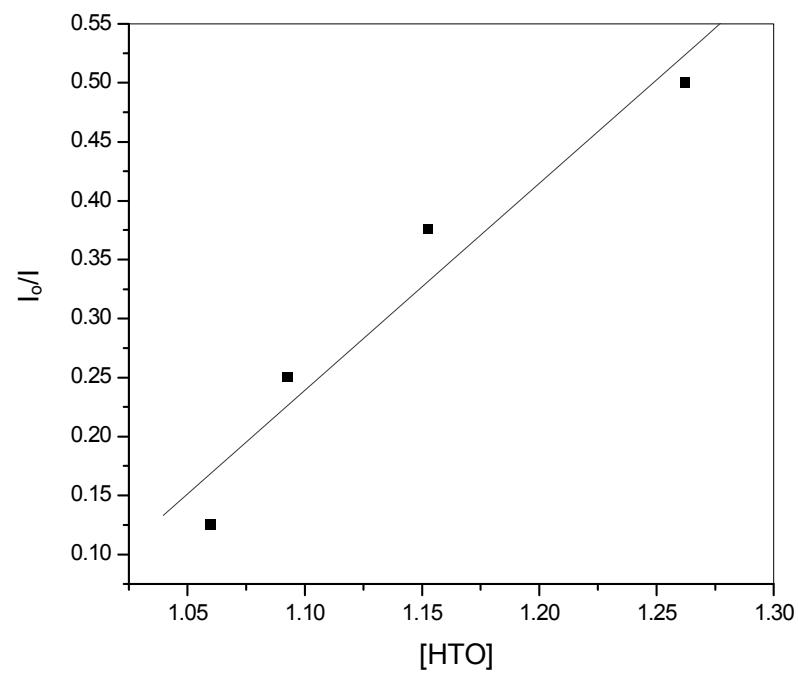

Figure 9. Plot of $\mathrm{I}_{0} / \mathrm{I}$ vs [HTO] for the titration of suspended aqueous solution of [HTO] to CT-DNA-EB system. where $\mathrm{A}_{0}$ and $\mathrm{A}_{\mathrm{c}}$ are the absorbance of BSA and complex respectively at $280 \mathrm{~nm}$ and Aobs is the observed absorbance of the solution containing different concentrations of suspended HTO at $280 \mathrm{~nm}$. From the plot of $\log \left[\mathrm{A}_{0}-\right.$ $\mathrm{A}] / \mathrm{A}$ vs $1 /[\mathrm{HTO}]$ (Figure 10) for the absorption titration of BSA with the HTO the $\mathrm{K}_{\text {ap }}$ was determined to be 5.41 $\times 10^{3}(\mathrm{R}=0.9558$ for four points). Fluorescence intensity of BSA at $280 \mathrm{~nm}$ shows the similar trend as the DNA which is mentioned earlier and the binding constant can be determined by Stern-Volmer equation as usual. In the quenching plot (Figure 11) of $\mathrm{I}_{0} / \mathrm{I}$ versus [HTO] for BSA-HTO interaction, $\mathrm{K}_{\mathrm{sv}}$ value is given by the ratio of the slope to intercept. The $\mathrm{K}_{\mathrm{sv}}$ value for the complex is $6.063 \times 10^{3}(\mathrm{R}=0.9953$ for four points $)$. The binding constant values for both cases $\left(\mathrm{K}_{\mathrm{ap}}\right.$ and $\left.\mathrm{K}_{\mathrm{sv}}\right)$ indicate a considerably strong affinity of the HTO to BSA.

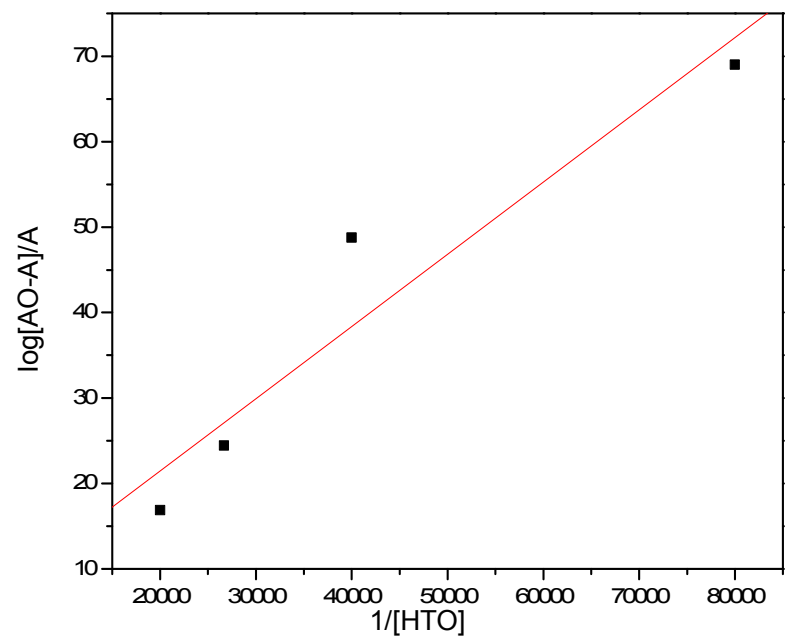

Figure 10. Plot of $\log \left[\mathrm{A}_{0}-\mathrm{A}\right] / \mathrm{A}$ vs $1 /$ [HTO] for the absorption titration of BSA with the HTO in aqueous medium.

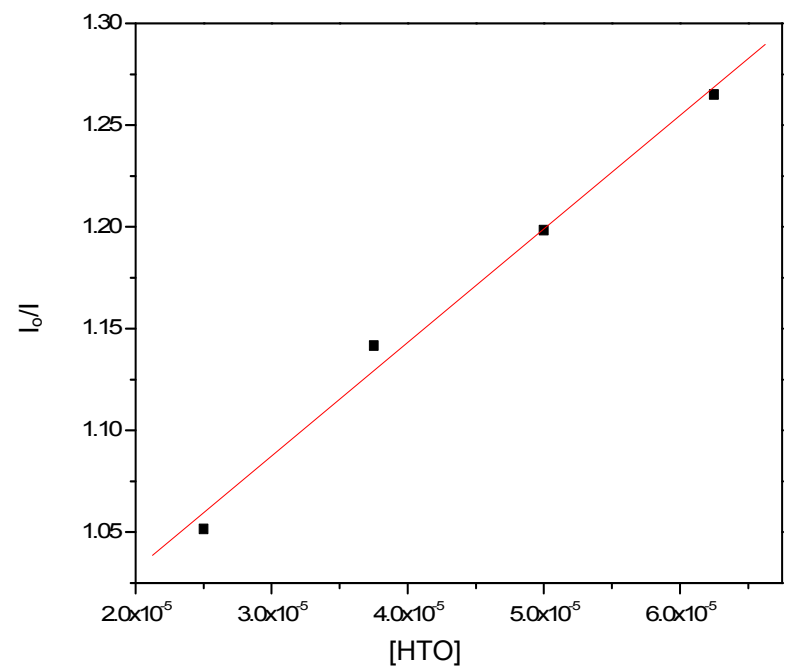

Figure 11. Plot of $I_{0} / I$ vs [HTO] for the titration of suspended aqueous solution of HTO to BSA. 


\section{Conclusion}

Study of photoinduced interaction between HTO and CT DNA using UV and fluorescence spectroscopic tools established that the interaction is quite strong which is also revealed by the high binding constant. The present work may be helpful in understanding the interaction between various photosensitizers and DNA. Clinical application of the existing photosensitizer is associated with some problems such as aggregation of photosensitizers in aqueous medium, decrease in quantum yield due to aggregation, toxicity etc. HTO nano particles can overcome all the above mentioned problems. This observation can also be considered with importance to investigate such interaction between nanotubes and DNA for future application in photodynamic therapy. This study of interaction of HTO with physiologically important BSA protein will provide some necessary information for the design and application of new drugs. ultrasensitive detection of proteins, clinical diagnostics etc.

\section{Acknowledgements}

Financial assistance from UGC-DAE Center for Scientific Research, Kolkata is gratefully acknowledged. The authors are obliged to Prof. P. Ayyub of Department of Condensed Matter Physics and Material Sciences, Tata Institute of Fundamental Research for providing TEM and SEM facilities.

\section{REFERENCES}

[1] S. Iijima, "Helical Microtubules of Graphitic Carbon," Nature, Vol. 354, No. 6348, 1991, pp. 56-58. doi: $10.1038 / 354056 \mathrm{a} 0$

[2] T. Kasuga, M. Hiramatsu, A. Hoson, T. Sekino and K. Niihara, "Titania Nanotubes Prepared by Chemical Processing," Advanced Materials, Vol. 11, No. 15, 1999, pp. 1307-1310.

doi:10.1002/(SICI)1521-4095(199910)11:15<1307::AIDADMA1307>3.0.CO;2-H

[3] H. Dai, "Carbon Nanotubes: Opportunities and Challenges," Surface Science, Vol. 500, No. 1, 2002, pp. 218241. doi:10.1016/S0039-6028(01)01558-8

[4] A. R. Armstrong, G. Armstrong, J. Canales and P. G. Bruce, "TiO 2 -B Nanowires," Angewandte Chemie International Edition, Vol. 43, No. 17, 2004, pp. 2286-2288. doi:10.1002/anie. 200353571

[5] D. Wu, X. Zhao, J. Liu, A. Li, Y. Chen and N. Ming, "Sequence of Events for the Formation of Titanate Nanotubes, Nanofibers, Nanowires, and Nanobelt," Cheistry of Material, Vol. 18, No. 18, 2006, pp. 547-553. doi: $10.1021 / \mathrm{cm} 0519075$

[6] G. R. Patzke, F. Krumeich and R. Nesper, "Oxidic Nanotubes and Nanorods-Anisotropic Modules for a Future Nanotechnology," Angewandte Chemie International Edi- tion, Vol. 41, No. 14, 2002, pp. 2446-2461.

[7] S. Matsuda and A. Kato, "Titanium Oxide Based Catalysts-A Review," Applied Catalysis, Vol. 8, No. 2, 1983, pp. 149-165. doi:10.1016/0166-9834(83)80076-1

[8] D. V. Bavykin, J. M. Friedrich and F. C. Walsh, "Protonated Titanates and $\mathrm{TiO}_{2}$ Nanostructured Materials: Synthesis, Properties, and Applications," Advanced Materials, Vol. 18, No. 4, 2006, pp. 2807-2824. doi:10.1002/adma.200502696

[9] O. K. Varghese, D. Gong, M. Paulose, K. G. Ong and C. A. Grimes, "Hydrogen Sensing Using Titania Nanotubes," Sensors and Acuators B, Vol. 93, No. 1, 2003, pp. 338-344. doi:10.1016/S0925-4005(03)00222-3

[10] T. Kasuga, M. Hiramatsu, A. Hoson, T. Sekino and K. Niihara, "Formation of Titanium Oxide Nanotube," Langmuir, Vol. 14, No. 4, 1998, pp. 3160-3163.

[11] Q. Chen, G. H. Du, S. Zhang and L. M. Peng, "The Structure of Trititanate Nanotubes," Acta Crystallography $B$, Vol. 58, 2002, pp. 587-590. doi:10.1107/S0108768102009084

[12] G. Raschke, S. Kowarik, T. Franzl, C. T. Solnnichsen, A. Klar and J. Feldmann, "Biomolecular Recognition Based on Single Gold Nanoparticle Light Scattering," Nano Letters, Vol. 3, No. 7, 2003, pp. 935-938.

[13] C. D. Hodneland and M. Mrksich,"Biomolecular Surfaces that Release Ligands under Electrochemical Control," Journal of the American Chemical Society, Vol. 122, No. 17, 2000, pp. 4235-4236.

[14] F. Patolsky, A. Lichtenstein and I. Willner, "Amplified Microgravimetric Quartz-Crystal-Microbalance Assay of DNA using Oligonucleotide-Functionalized Liposomes or Biotinylated Liposomes," Journal of the American Chemical Society, Vol. 122, No. 2, 2000, pp. 418-419. doi:10.1021/ja992834r

[15] T. Paunesku, T. Rajh, G. Wiederrecht, J. Maser, S. Vogt and N. Stojićević, "Biology of $\mathrm{TiO}_{2}-$ Oligonucleotide Nanocomposite," Nature Materials, Vol. 2, No. 5, 2003, pp. 343-346. doi:10.1038/nmat875

[16] T. Rajh Saponjic, Z. Liu, J. Dimitrijevic, N. M. Scherer, N. F. Vega-Arroyo, M. Zapol, P. Curtiss and L. A. Thurnauer, "Charge Transfer across the Nanocrystalline-DNA Interface: Probing DNA Recognition," Nano Letters, Vol. 4, No. 6, 2004, pp. 1017-1023. doi:10.1021/n1049684p

[17] R. K. Behera, S. Goyal and S. Mazumdar, "Modification of the Heme Active Site to Increase the Peroxidase Activity of Thermophilic Cytochrome P450: A Rational Approach," Journal of Inorganic Biochemistry, Vol. 104, No. 11, 2010, pp. 1185-1194.

[18] M. Ray, S. Chatterjee, T. Das, S. Bhattacharyya, P. Ayyub and S. Mazumdar, "Conjugation of Cytochrome C with Hydrogen Titanate Nanotubes: Novel Conformational State with Implications for Apoptosis," Nanotechnology, Vol. 22, 2011, pp. 415705-415713.

[19] S. Chatterjee, K. Bhattacharyya, P. Ayyub and A. K. Tyagi, "Photocatalytic Properties of One-Dimensional Nanostructured Titanates," The Journal of Physical Chemistry C, Vol. 114, No. 20, 2010, pp. 9424-9430. 
doi:10.1021/jp1016642

[20] G. H. Du, Q. Chen, R. C. Che, Z. Y. Yuan and L. M. Peng, "Preparation and Structure Analysis of Titanium oxide Nanotubes," Applied Physics Letters, Vol. 79, No. 22, 2001, pp. 3702-3705. doi:10.1063/1.1423403

[21] L. A. Sklar, B. S. Hudson and R. D. Simoni, "Conjugated Polyene Fatty Acids as Fluorescent Probes: Binding to Bovine Serum Albumin," Biochemistry, Vol. 16, No. 23, 1977, pp. 5100-5108. doi:10.1021/bi00642a024

[22] D. Gao, Y. Tian, F. Liang, D. Jin, Y. Chen, H. Zhang and $\mathrm{Yu}$. Aimin, "Investigation on the $\mathrm{pH}-\mathrm{Dependent} \mathrm{Binding}$ of Eosin Y and Bovine Serum Albumin by Spectral Methods," Journal of Luminescence, Vol. 127, No. 2, 2007, pp. 515-522. doi:10.1016/j.jlumin.2007.02.062

[23] H. W. Zhao, M. Ge, Z. X. Zhang, W. F. Wang and G. Z. $\mathrm{Wu}$, "Spectroscopic Studies on the Interaction between Riboflavin and Albumins," Spectrochimica Acta A, Vol. 65, No. 3-4, 2006, pp. 811-817. doi:10.1016/j.saa.2005.12.038

[24] Y. B. Yin, Y. N. Wang and J. B. Ma, "Aggregation of
Two Carboxylic Derivatives of Porphyrin and Their Affinity to Bovine Serum Albumin," Spectrochimica Acta Part A, Vol. 64, No. 4, 2006, pp. 1032-1038. doi:10.1016/j.saa.2005.09.012

[25] A. Kathiravan and R. Renganathan, "Photoinduced Interactions between Colloidal $\mathrm{iO}_{2}$ Nanoparticles and Calf Thymus-DNA," Polyhedron, Vol. 28, No. 7, 2009, pp. 1374-1378. doi:10.1016/j.poly.2009.02.040

[26] A. Kathiravan, R Renganathan and S. Anandan, "Interaction of Colloidal $\mathrm{AgTiO}_{2}$ Nanoparticles with Bovine Serum Albumin," Polyhedron, Vol. 28, No. 1, 2009, pp. 157-161.

[27] A. M. Pyle, J. P. Rehmann, R. Meshoyrer, C. V. Kumar, N. J. Turro and J. K. Barton, "Mixed-Ligand Complexes of Ruthenium(II): Factors Governing Binding to DNA," Journal of the American Chemical Society, Vol. 111, No. 8, 1989, pp. 3051-3058.

[28] O. Stern and M. Volmer, "Über die Abklingzeit der Fluoreszenz," Zeitschrift für Physik, Vol. 20, 1919, pp. 183188. 